\title{
MORAL VALUES OF THE CHARACTERS AND CHARACTERS ANALYSIS IN THE NOVEL 'READY PLAYER ONE' BY ERNEST CLINE
}

\author{
Henny Belgrita Ginting ${ }^{1}$, \\ Graduate Faculty, English Language Teaching Program \\ Universitas Indraprasta PGRI, Jakarta \\ e-mail: hennyginting03@gmail.com ${ }^{1}$
}

\begin{abstract}
The purpose of the research is to demonstrate the moral values and characters in the novel "Ready Player One" by Ernest Cline. This research is designed as qualitative research. The approach that the writer used is the qualitative approach. The data are collected by analyzing the data found in the novel. The analysis of the novel is observed in the text and dialogues. The results of the research are in the form of moral values and characters analysis. 1) The moral values in the novel are: Justice is $34,62 \%$, honesty is $26,92 \%$, responsibility is $23,08 \%$, and beneficence is $15,38 \%$. 2) The characters which emerge in the novel "Ready Player One" Protagonist are 55,86\%, Foil is $37,93 \%$, and the antagonist is $6,21 \%$. Moral values that dominate, or the novel would like to convey particularly to the readers, are Justice and Honesty. It means that the character who dominates the film is the protagonist.
\end{abstract}

Keywords: moral; value; moral value; character; novel

\section{Introduction}

Literature is a form of creative and productive activity in producing work that has an aesthetic value and reflects the reality of social life. A novel is a form of literary work that has its characteristics. The novel has a very close relationship with short stories. Both forms of literary work require depicting a creative life, which is fundamental to real life, or literature mimicking life. Sometimes, literature portrays historical events as compared in the 'The Butler' movie and actual historical events of the Black people in the United States during a specific period in the past (Harang et al., 2019). The portrayer of the novel can be created by the presence of characters that run in a coherent and appropriate path. The novel is constructed from intrinsic and extrinsic elements. Intrinsic elements build a story from the inside, including plot, character and characterization, theme, setting, point of view, language, and mandate. Extrinsic elements build literary work in terms of author, politics, culture, religion, social and economic biographies.

The general characteristics of the novel include (1) the plot, (2) the characters, (3) the setting, and (4) the theme. "Ready Player One" is a literary work exploring a complex life that occurs in the 2045s regarding modern life where people rely on technological sophistication and almost forget religious values in their lives. It seems that they can live with their strength. They have to live harsh lives. They use their egos to face their social life. However, in its climax, moral values also emerge in the lives of its main characters. This novel is a New York Times best-seller that gives rise to elements favored by young people, namely the social life of young people with the computer world. Sophisticated computer technologies attract all city citizens in the year 2045, making them run away from reality. The need for sophisticated computer technologies also makes it the most dominant part of the citizens' real lives. "Reality is an ugly place" is what is written in a summary of this novel. Concerning the above quotation, the novel readers can understand how damaged their life was in the era. In that year, the individualistic nature/importance of one's interests was very dominant in the lives of the citizens of the city. In this story, the readers also get an overview of life in the hectic computer business world and, sometimes, make workers think about business targets set by top management (highly level superior). The superiors only know that their workers can reach their target without considering their welfare and health. This condition is also happening in many 
companies presently. The employees working in that company do not have time to think about their personal lives. Their lives are only for working, working, and working. This situation can be seen clearly in the movie. The employees worked like robots and, although they had worked very hard, received no rewards from the company. They worked in IOI (Innovative Only Industries) only for paying their debts. After the outstanding debts are settled, they are bound by other work agreements that make it impossible for these IOI employees to breathe in the fresh air. Wade Watt once experienced IOI's work condition (using a false identity) but, after working for several months, Wade Watt successfully ran away from IOI. Wade Watt (a protagonist character), when he won Halliday's first-level contest (using his true identity), was again offered to join IOI. However, he declined the offer since Wade Watt knew the risks of accepting the offer.

The novel is also wrapped in the romance life of the protagonist character and also told in this story, a relative of the main character (Wade Watt) who embraced "a free-sex life" busy changing boyfriends. Wade Watt was in love with Artemis, an innovative and sexy avatar, and believed that Artemis had the same image as her avatar. Having followed the blog of a female hunter named Artemis for three years and as the loyal reader in Artemis' blog, Wade Watt could not deny that he fell in love with Artemis. Wade Watt did not like the lifestyle of his aunty but could not help advising his aunty as he knew that his aunty would not listen to his words, and the aunty was his only relative that he had in this world. The existence of human greed for money also seemed dominant in the lives of the novel's antagonist characters. At the end of the story, the truth would always win over the evil. This is the basic rule of life that the people cannot deny it.

Novel Ready Player One by Ernest Cline is suitable for energetic-young people and young-minded readers who have no time for self-introspection. The language style used in telling the characters' lives is everyday' s English and added slang terms that add to the English vocabulary for young people who read it. Young people tend to violate God's words since rebellious persons are usually luckier than obedient people to God's words during their stay on earth. In this novel, the young people can learn that whatever happens to the people, they try to be good and obedient persons since there is a God, the creator of the universe, although the present people mostly do not care about the Lord.

The reason for raising this novel in research is the uniqueness of the life of the future character (the readers have not yet passed). However, it is the writer's concern with the existence of a civilization that does not emphasize faith in God (the spiritual/religious life in this novel is not raised, but it is still written that the natural process still exists that some people are alive and some people are dead). However, they seem to forget the principles of religion, but God's bits of help is still needed in their daily lives.

It is interesting to explore one's life more deeply even though this is a fiction novel, but the thesis readers can examine their view of life. Possessing moral values such as justice, honesty, responsibility, and beneficence can be a good reason for struggling people's lives. Talking about the novel's moral values can be implemented in readers today's lives.

As described in this novel, there is a main character called Wade Watt. He lived alone where he was no longer had relatives, but he was able to create love and a family atmosphere for his friends in his complicated life. This is the side that the readers can learn from Wade Watt's life that people's lives, which are built and owned, can be something fun, enjoyable, and engaging. People will have the conditions subject to people's choice. A unique life story becomes an exciting thing to observe. Therefore, it is necessary to present the above-mentioned moral value to the thesis readers to adopt the moral values in their lives. The research taken from this novel has never been studied before, and it is interesting to learn it more deeply. This novel has also been aired in theaters so that it is easier to get a clear picture of what is told in the novel. It is also interesting to learn about how to build a happy life that requires struggles and sacrifices.

Having read the novel, the willingness to demonstrate moral values of the characters and characters analysis for the thesis readers suddenly comes up. To realize this willingness, it is expected that the thesis readers can learn more about moral values such as justice, honesty, responsibility, and beneficence and have the confidence to implement the moral values in the readers' lives. The readers can also learn how to analyze three characters from the novel: protagonist, antagonist, and foil characters (Wellek \& Warren, 1989). The readers can get informed about the characters and have a clearer picture by reading their theories in chapter two of this research.

Some theories concerning protagonist, antagonist, foil characters and moral values can guide the analysis. Stressing on the novel analyzed, the research results are expected to become people's learning process material. 
In the writing of this novel, it is evident that there is a good and evil side and the protagonist, antagonist, and foil characters. Halliday was a person who was not successful in his romantic life as he did not express his feelings for his lovely lady. Finally, Halliday's lovely lady gave her heart to another young man who was also a friend of Halliday. Learning from this novel, it is clearly shown that many things in this life must be brave enough to grab their happiness. The moral values contained in this novel can be some guidelines in facing real modern life.

Regarding improving students' knowledge, it is necessary to explore and analyze the novel in terms of grammar, writing style, and the way to convey the messages explicitly and compare to the homeland novelists. Ernest Cline (the novel's author) described and conveyed moral values and characters in perfect ways, and it is good to learn it, especially for Indonesian novelists. The Indonesian novelists can learn how to make an essay or literary work and improve the novelists' English know-how in making a best-seller novel. It is also necessary to learn about how to choose diction (word choice) to make the novel appealing for the novel readers. Writing a literary work can be learned appealingly. This writing skill is good to learn deeply. It can be implemented in other work segments, such as presenting attractive reports for businesses, school principals, and other superiors and organizations. This is the benefit that can be gathered from different English literature.

In this life, nothing is specific and only death is inevitable. People's lives are always up and down, and people must anticipate what will happen in their lives by acquiring as many different skills as possible. Learning how to make a good novel is one of the different skills which the novel readers can pass. People cannot predict what will happen to them in the next ten years. Nevertheless, if the people are ready to face the uncertain life, they can solve their problems well, especially in fulfilling their family's daily needs. By possessing writing skills, people can get some advantages which can be used for their future lives. Based on the research background/aim above, it is concluded that it is needed to research with the title: "Moral values of the Characters and Characters Analysis in the Novel "Ready Player One" by Ernest Cline."

\section{Method}

This research aims to discover and describe moral values and characters in the novel entitled "Ready Player One" (Cline, 2018). Good research will result in an excellent accountable, and credible study. Good research needs a suitable, appropriate, and accountable method. Every researcher wishes that the research he or she has done will result in a credible and accountable result. To reach the goal mentioned earlier, the researcher uses the qualitative method to interpret and present the research in a descriptive method. Herewith, it is tried to quote one of the experts' opinions regarding the qualitative method. According to Creswell (2012, p. 262):

\section{Qualitative research is an inquiry approach useful for exploring and understanding a central phenomenon. To learn about this phenomenon, the inquirer asks participants broad, general questions, collects the detailed views of participants in the form of words or images, and analyzes the information for description and themes. From these data, the researcher interprets the meaning of information, drawing on personal reflections and past research. The final structure of the final report is flexible, and it displays the researcher's biases and thoughts.}

Based on the statement above, it can be seen that qualitative research is research which is conducted based on the central phenomenon which is to analyze, interpret, and collect some information related to sure participants based on the phenomenon chosen by the researcher, being researched and is described in the form of words or figures if necessary. It does not describe the numerical analysis from the researcher's interpretation and personal reflections. The description is flexible, and it displays the researcher's biases and thoughts.

According to Bogdan \& Knopp (2003), it is stated that qualitative research is one of the research procedures which results from descriptive data in the form of statement/utterance or writing. Using qualitative research can result in descriptive data that the researcher does. These data are yielded by deep description regarding utterance, writing, or attitude in certain conditions, which is observed from the 


\section{INFERENCE: Journal of English Language Teaching}

Vol. 4, No. 3, December 2021 - March 2022

p-ISSN: 2615-8671

e-ISSN: 2615-868X

complete viewpoint, comprehensive and holistic. Afterward, the data acquired from this research are analyzed and then yield a descriptive detail concerning collected data explanation.

A qualitative approach is a type of social science research approach collecting and working with non-numerical data and seeking to interpret meaning from these data to help us understand social life by studying the targeted object of the research (Endraswara, 2008). Content analysis is research in which focuses on analyzing the content of the document or textual data. Krippendorf (2004:30) said that content analysis is a research technique replicable and valid interferences from the text (or other meaningful matter) to the context of their use. It means that content analysis is a technique used for conducting research that the other researcher can re-use. The valid interferences are adopted from the text (or other written documents which are essential), and they are used appropriately. This research aims to collect information taken from the data as much as possible. After the data is gathered, they must be interpreted to achieve the aim which has been determined.

\section{Results and Discussion}

There are four kinds of moral values found in the novel "Ready Player One" by Ernest Cline. They are (1) Justice, (2) Honesty, (3) Responsibility, (4) Beneficence.

\section{Justice}

Justice is fairness in the protection of rights and punishment of wrongs. Justice is always talking about how to treat someone or something reasonably and shows their true qualities. People who believe in justice usually do something somewhat, and they try not to cheat others. They treat other people based on specific rules to which certain communities have agreed.

\section{Honesty}

Honesty is speaking the truth. An honest person does not do morally wrong things. If something you do is breaking the law or if you must hide what you are doing, it means that you are not honest. Honesty is speaking and acting truthfully. Honesty means you do not say things about people that are not true. Being honest means you explain how the situation happened. Seven quotations can be found from the novel, which shows Honesty.

\section{Responsibility}

Responsibility is related to doing what we are supposed to do and accepting responsibility's positive or negative outcome. Being responsible means, you do the things you are expected to do and accept the consequences or the results of your actions. A responsibility might be at a task you are expected to do. Responsibility also means a way you are expected to act.

\section{Beneficence}

Beneficence is the act of doing good. Beneficence is defined as charity, mercy, and kindness with a strong connotation of doing good to others, including moral obligation. If you show someone your kindness or generosity, that is beneficence. Helping someone just because you care instead of expecting to be praised for being nice. Giving your time, skills, or even a donation of money or items shows the character of beneficence. Beneficence can also describe the character of a person who is helpful, caring, and compassionate. Below is the result of the Moral Value of the Characters. The results are presented in table and chart:

Table 1. Percentage in Percent (\%) of Moral Value of the Characters

\begin{tabular}{|l|l|c|c|}
\hline No. & \multicolumn{1}{|c|}{ Kinds of Moral Value } & Times of Show Up & Percentage \\
\hline 1 & Justice & 9 & $34,62 \%$ \\
\hline 2 & Honesty & 7 & $26,92 \%$ \\
\hline 3 & Responsibility & 6 & $23,08 \%$ \\
\hline 4 & Beneficence & 4 & $15,38 \%$ \\
\hline & & 26 & $100 \%$ \\
\hline
\end{tabular}


There are three kinds of characters presented in this writing. The kinds of characters are protagonist, antagonist, and foil.

\section{Protagonist}

The protagonist is the main character in the novel story. It also functions as a leading character in the story. The protagonist's role is usually a good character and easy to be identified. A protagonist is usually defined by the frequency of problems this character faces and how this character can overcome the problems. In this novel, the protagonist is only one person who is Wade Watt. The story, it presents by the pronoun "I."

\section{Antagonist}

The antagonist is the principal source of conflict for the protagonist. It is the proponent or advocate of a cause. Often the antagonist is a bad guy, a villain, against whom a hero. The antagonist might be one person, a group, or even an animal. Usually, it is easy to define the antagonist, but sometimes it is not always easy to distinguish between the protagonist and antagonist. In this novel, the antagonists are Nolan Sorento and his team from IOI (Innovative Online Industries). The IOI was usually called "The Sixers." They tried to do bad things to prevent other people from winning Halliday's contest.

\section{Foil}

A foil character is a character that shows qualities that contrast with the qualities of the other characters. The objective of the foil character is to highlight the traits of the other characters. In fiction, the foil character is vital in the development of the story's characters. Foil exhibits opposite or conflicting traits to the other characters. Foil characters can be an antagonist, but not always. Sometimes, the foil will even be the other characters alongside the protagonist. In this novel, the Foil is Art3mis (Samantha), Aech (Helen Harris), Shoto (Akihide) and Daito (Toshiro Yoshiaki), Ogden Morrow, and finally James Halliday.

Table 2. The percentage of Characters

\begin{tabular}{|l|l|c|c|}
\hline No. & Kinds of Character & Times of Show Up & Percentage \\
\hline 1 & Protagonist & 81 & $55,86 \%$ \\
\hline 2 & Foil & 55 & $37,93 \%$ \\
\hline 3 & Antagonist & 9 & $6,21 \%$ \\
\hline & & 145 & $100 \%$ \\
\hline
\end{tabular}

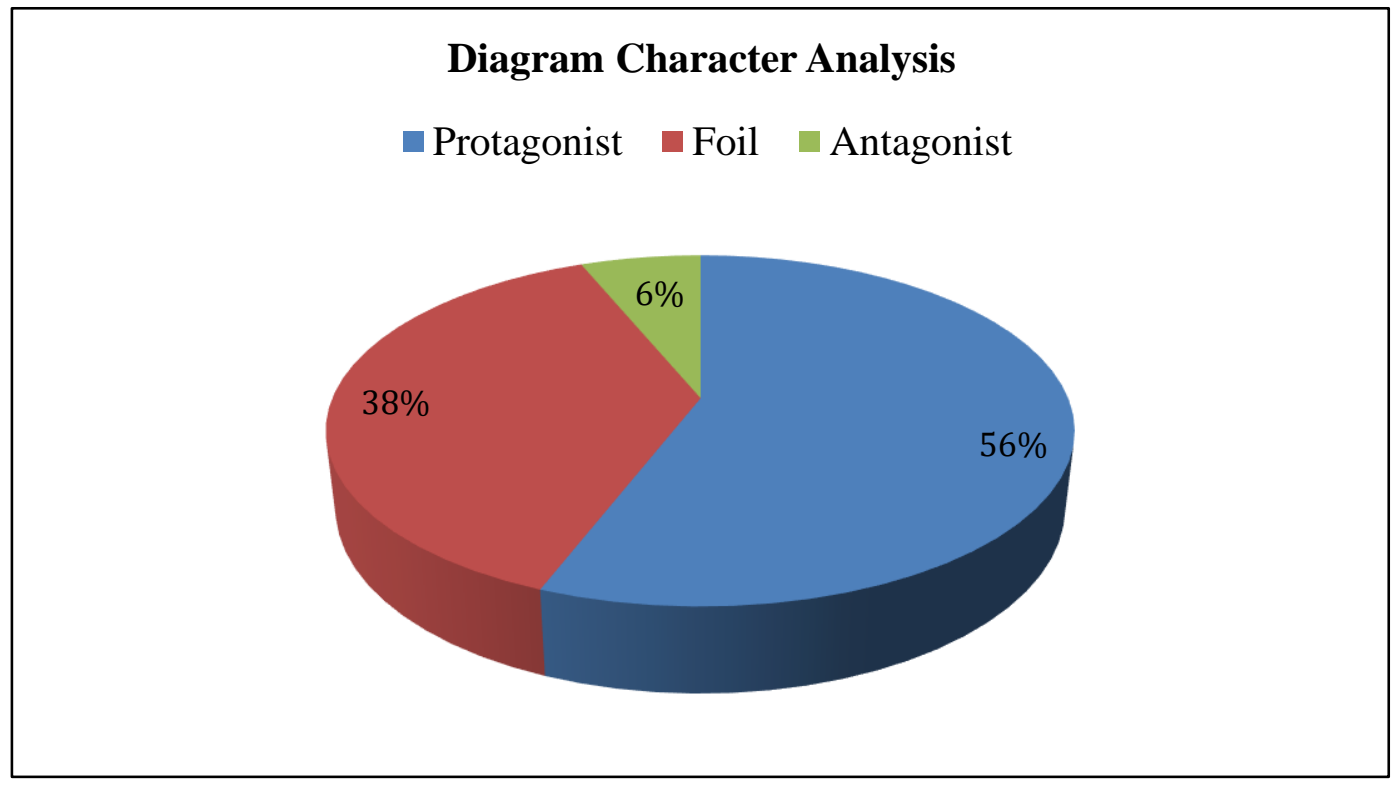

Figure 1. Results from the Protagonist, Antagonist, and Foil Characteristics

After the analysis has been done, the researcher concluded that in the novel entitled "Ready Player One" by Ernest Cline, it could be indeed concluded that there are 26 data that have something to do with kinds of moral values and 145 data which have something to do with kinds of characters. The analysis has 
INFERENCE: Journal of English Language Teaching

Vol. 4, No. 3, December 2021 - March 2022

p-ISSN: 2615-8671

e-ISSN: 2615-868X

two objectives. The first objective is to analyze the moral values that the novel wants to convey to the readers, and the second is to analyze the characters the novel reveals.

\section{Conclusions}

There are four kinds of moral values in the novel "Ready Player One" by Ernest Cline. They are Justice, Honesty, Responsibility, and Beneficence. The writer can conclude that the moral value emerges in the novel "Ready Player One": Justice is $34,62 \%$, Honesty is $26,92 \%$, responsibility is $23,08 \%$, beneficence is $15,38 \%$. Justice and Honesty get the highest percentage since the novel author tries to deliver a message that possessing the moral value of justice and Honesty is more important for the readers. In every aspect of our lives, possessing justice and Honesty is a must. We can be promoted to a higher level at the office since our superior appreciate our moral behavior and fair attitude to other staff. Therefore, the novel author thinks that the readers should appreciate learning more about this moral value. The author also teaches the readers that good guys will always win in the end as we still have a God who does not focus on our lives. Nothing is accidental in this life. It is truly hoped that every person is reading the novel willing to apply the moral values in their everyday' s living. Moral values of responsibility and beneficence do not mean that it is less critical, but we can learn them after acquiring the traits of justice and Honesty in our lives. In Christian values, it is taught that it is suitable for being beneficence as it can promote the goodness of our Lord to other people. It is also good to be a responsible person as everybody will be pleased and respect you. It is concluded that moral values of responsibility and beneficence are also essential to imitate the novel readers.

There are 3 (three) characters in the novel "Ready Player One" by Ernest Cline. The Protagonist character, Antagonist character, Foil character. The protagonist is the most dominant character in the novel with $55,86 \%$, the foil is $37,93 \%$, and the antagonist gets $6,21 \%$. The protagonist character gets the highest percentage because this novel is about the life of a young man whose name is Wade Watt. The protagonist gets the highest percentage because the protagonist usually has a good character, which can inspire the readers to learn from this character to possess good personality traits. This novel also teaches how to love other people, overcome problems, and be a good person. The antagonist gets the lowest percentage. It is not surprising since the antagonist in this novel, Nolan Sorrento, is an arrogant, selfish, greedy, mean, and tricky man. This character is not good to be imitated by everybody. It is not a good character. Getting the lowest percentage showed these characters must be avoided.

\section{References}

Bogdan, R., \& Knopp, S. (2003). Qualitative Research for education : An Introduction to Theory and Methods. In Qualitative Research. https://doi.org/10.1177/1468794107085301

Cline, E. (2018). Ready Player One. Penguin Random House.

Creswell, J. W. (2012). Educational research: Planning, conducting, and evaluating quantitative and qualitative research. In Educational Research. https://doi.org/10.1017/CBO9781107415324.004

Endraswara, S. (2008). Metodologi Penelitian Sastra (2nd ed.). Pustaka Widyatama.

Harang, H., Engliana, E., \& Supadi, S. (2019). Sketching historical context in Lee Daniel'S "the Butler": A mimetic approach. LiNGUA: Jurnal Ilmu Bahasa Dan Sastra, 14(1), 169. https://doi.org/10.18860/ling.v14i1.6633

Wellek, R., \& Warren, A. (1989). Teori kesusasteraan. Gramedia Pustaka Utama. 